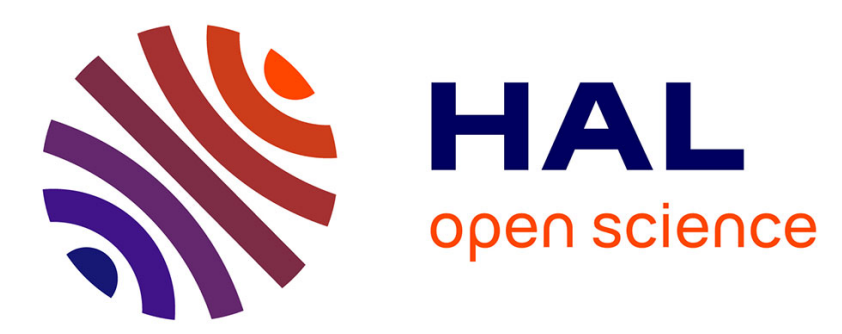

\title{
The evolution of taste perception: psychophysics and taste nerves tell the same story in human and non-human primates
}

Claude Marcel Hladik, Patrick Pasquet, V. Danilova, G. Hellekant

\section{To cite this version:}

Claude Marcel Hladik, Patrick Pasquet, V. Danilova, G. Hellekant. The evolution of taste perception: psychophysics and taste nerves tell the same story in human and non-human primates. Comptes Rendus. Palevol, 2003, 2 (4), pp.281-287. hal-00276544

\section{HAL Id: hal-00276544 \\ https://hal.science/hal-00276544}

Submitted on 9 Dec 2010

HAL is a multi-disciplinary open access archive for the deposit and dissemination of scientific research documents, whether they are published or not. The documents may come from teaching and research institutions in France or abroad, or from public or private research centers.
L'archive ouverte pluridisciplinaire HAL, est destinée au dépôt et à la diffusion de documents scientifiques de niveau recherche, publiés ou non, émanant des établissements d'enseignement et de recherche français ou étrangers, des laboratoires publics ou privés. 


\section{The evolution of taste perception: psychophysics and taste nerves tell the same story in human and non-human primates}

L'évolution de la perception gustative : les données psychophysiques et les réponses des nerfs de la gustation correspondent à la même histoire évolutive de l'homme et des primates non humains

\section{Claude Marcel Hladik ${ }^{1{ }^{\circ}}$, Patrick Pasquet ${ }^{\circ}$, Vicktoria Danilova ${ }^{\circ}$, Göran Hellekant ${ }^{\circ}$}

aMuséum National d'Histoire Naturelle et CNRS, Éco-Anthropologie, 4 avenue du Petit Château. F 91800, France e-mail:hladik@ccr.jussieu.fr

${ }^{`}$ CNRS, Dynamique de l'Évolution Humaine, 44 rue de l'Amiral Mouchez, 75014 Paris, France

‘University of Wisconsin, Department of Animal Health and Biomedical Sciences, Madison, WI 53706, USA

Résumé - Les signaux enregistrés sur les fibres du nerf gustatif de différentes espèces de primates non humains sont corrélés selon un arbre additif qui présente une double ramification : d'une part les signaux correspondant aux substances bénéfiques (des sucres), d'autre part les signaux provoqués par des substances susceptibles d'être toxiques (des tannins et des alcaloïdes) qui se distinguent clairement de tous les autres stimuli gustatifs. Chez l'homme, on retrouve la même dichotomie des perceptions gustatives que pour les autre primates à partir des corrélations entre les seuils de reconnaissances, avec, en particulier une corrélation entre la perception des tannins et celle des alcaloïdes. La convergence des résultats obtenus par ces deux approches montre que les pressions de sélection ont favorisé l'émergence d'ensembles de récepteurs qui ne correspondent pas aux "goûts de base" classiquement décrits en psychophysiologie.

nerfs gustatifs / goûts de base / seuils de reconnaissance / sucres / tannins / alcaloïdes

Abstract - As shown by clustering in additive trees of the signals recorded on isolated nerve fibers, the primate tasting system is basically a two-way system that allows discriminating what is beneficial from what could be toxic (sugars vs tannins and alkaloids) among a large number of chemical stimuli. In humans, using psychophysical data (recognition taste thresholds) with a similar method of analysis, we observed the same dichotomy as in the rest of the Primate Order, and similar links between perceived tastes such as those of alkaloids and tannins. The 
converging results obtained by both methods show that the target of evolutionary pressure was a set of taste receptors that were not initially tuned to respond to what is presently described as basic tastes.

gustatory nerves / basic tastes / recognition thresholds / sugars / tannins / alkaloids

\section{Introduction}

During the Cenozoic when plants bearing fleshy fruits appeared, selective pressure was exerted on the primate tasting system to enable the various species to perceive and identify, either beneficial, or toxic constituents of the foods available in these changing environments [1]. To maximise ingestion of beneficial substances, gene(s) would have been selected to promote a set of taste receptors triggering a positive response towards sugars. Similarly, selective pressure led to the development of adequate avoidance responses to compounds likely to be toxic, the most common being alkaloids and tannins. Our recent studies of taste responses of humans and non human primates show the result of such selective pressure.

\section{Methods}

In humans, data on recognition thresholds were obtained during blind tests using verbal recognition of tastes with solutions (including fructose, sucrose, sodium chloride, citric acid, tannic acid, oak tannin and quinine hydrochloride) at increasing concentration in a step-wise fashion [2-3].

In anaesthetised marmoset, rhesus monkey and chimpanzee, the number of impulses per second was recorded from single nerve taste fibres while their tongues were stimulated with solutions at above threshold concentration [4-8].

Here, we selected, among data obtained in several of our published or unpublished studies, those concerning compounds used for both non-human primates and humans, to show, for each species, similarities/dissimilarities of responses between the compounds used as stimuli. Each set of data was subjected to additive trees clustering [9] for modeling similarity/dissimilarity data, using SYSTAT (version 9.0) statistical software (SPSS Inc., Chicago). The radial representation of the trees (not provided by SYSTAT) was drawn using the T-Rex Program (freely available at www.fas.umontreal.ca/BIOL/Casgrain/en/labo/t-rex/index.html). 


\section{Results}

Additive trees are presented in Figures 1 and 2. Stress indices of each tree are low $(<5 \%)$, thus indicating good representation of the data concerning 412 human subjects (Fig. 1), and, for each species of non-human primates (Fig. 2) about 50 isolated taste fibres. Results obtained from studies of humans and in non-human primates appear remarkably similar with regard to the relationships between taste perception of different compounds, although the methods used for recording taste responses in the different studies were very specific.

The human data (Fig. 1) show that if an individual has a high sensitivity to sucrose he/she will also show a high sensitivity to fructose. Although co-variation is a clear indication that most receptors involved in sucrose perception are also involved in tasting fructose, the moderate correlation level obtained suggests that various sugars may not elicit exactly the same taste signal. More striking is the correlation between perceptions concerning quinine and the two tannins (tannic acid and oak tannin), shown by relatively short distances in the additive tree. The bitter taste of several alkaloids obviously differs from the astringency of most tannins (whose peculiar taste [10] is not a mere tactile perception due to precipitation of salivary protein). Again, the co-variations found in this alkaloid/tannin cluster might reflect the responses of partially overlapping sets of taste receptors. Covariation in individuals' sensitivities to bitter compounds was also presented by Delwiche et al. [11] as an evidence supporting multiple receptor/transduction mechanisms. Furthermore, our data show that sensitivity to sucrose or fructose varies independently of sensitivity to quinine and tannins. Hence, no significant set of taste receptors responds to both sugars and alkaloid/tannin.

The non-human primate taste fibre data (Fig. 2) allows a further step in understanding the functioning of the peripheral taste system. In the three species, individual taste fibres highly responsive to sucrose are also responsive to fructose. As for human taste thresholds, distances between these carbohydrates are short in the additive trees. However, correlations vary to some extent among primate species. For instance, in the rhesus monkey, Macaca mulatta (Fig. 2 B), fructose and sucrose may be partly discriminated at a peripheral level [6].

In the three non-human primates investigated, there is also a clear relationship between responses to quinine and tannic acid (when tested), and other compounds that taste bitter or astringent to humans, such as caffeine and aristolochic acid. One single taste fibre can be involved in the signalling of these various compounds (and, in some instances, of citric acid) $[4-6,8]$. Furthermore, a high response to soluble sugars in an individual taste fibre involves a low response (or no reaction) to quinine, tannins, or to various other compounds including salts 


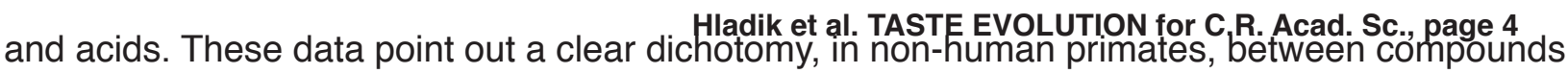
likely to be toxic (perceived as bitter or astringent in humans) and compounds likely to be beneficial (perceived as sweet in humans).

\section{Discussion}

\subsection{Behavioural and morphological dichotomy}

In terms of primate feeding behaviour, the dichotomy in taste discrimination is reflected by a preference for sugars and a rejection of most alkaloids and tannins [8]. The so-called "gusto-facial reflex", observed in the new-born of various species including Homo sapiens [12], highlights the innate nature of this dichotomy, allowing infants to swallow sugars and to spit out quinine. The reflex can be understood in light of the evolutionary history of the Primate Order. Selection pressure led to the co-evolution of the angiosperms producing fleshy fruits with increasing content of soluble sugars (fructose, sucrose and glucose) and frugivorous seed dispersers (birds and primates) with increasing taste sensitivity and preference for sugars [13]. The high energy needs in the largest species was met with the highest sensitivity to fructose [14]. Conversely, the occurrence of alkaloids, tannins, and various other more or less toxic compounds in plants should have co-evolved with the ability of primates (and other vertebrates) to taste what is presently described as bitter or astringent in the human repertoire. Although several kinds of taste receptors may be responding to various compounds perceived as bitter, as shown by the number of putative G-protein-coupled receptors [15], the topological grouping of fibres responding to aversive substances and their cortical projection is a likely evolutionary step towards an efficient gusto-facial reflex.

Indeed, between the front and the back of the tongue there seems to exist a major dichotomy between 'bitter' and 'sweet' in higher primates, as judged by taste nerve recordings from the rhesus monkey [6]. The front of the tongue is innervated by the chorda tympani nerve (CT) while the glossopharyngeal (NG) mediates taste from the back, a morphological trait shared by mammals including higher primates. Among single fibres from the CT and NG nerves of rhesus monkey a majority responded to sugars in the CT (16 out of 47 fibres versus only 4 responding to quinine), whereas the majority in the NG (20 out or 33 fibres) responded to quinine, as compared responding to sugars. Furthermore the average response to sucrose in the fibres of the CT was 23.9 impulses per sec (SD 2.7) as compared to 11.3 impulses per sec (SD 2.3) in the few fibres of the NG responding to sugars. Thus, not only are there many more fibres eliciting a signal for sugars from the front of the tongue than from the back, but also they are more sensitive to the same stimulus. 


\subsection{Why are there so many taste responses?}

Among bitter compounds, the well known examples of PTC (phenylthiocarbamide) and PROP (6-n-propylthiouracil) involving various proportions of 'tasters' and 'non-tasters' in human populations [16-18] were considered to be the best way to understand taste genetics. However this factor, which has been tested in our studies on human thresholds [3], is independent of the sensitivity to other substances, including alkaloids/tannins. If we introduce this variable into the correlation matrix for human thresholds, there is no change in the shape of the additive tree shown in Figure 1. It still appears as a robust model for the dichotomy sugars vs. alkaloid/tannins, with just a separate branch for the PROP status, as for sodium chloride and citric acid sensitivity.

The large variety of taste responses for various compounds probably reflects an initial variety of taste receptors that allowed co-evolution with plants producing a wide array of compounds. But one may wonder why human taste thresholds for citric acid and sodium chloride co-vary poorly with thresholds for other compounds. Perception of acids might have been subjected to selective pressure for innate rejection, as for tannins/alkaloids. There is evidence that foods with a low $\mathrm{pH}$ are avoided by primate species when the symbiotic flora in their digestive tract could be strongly disturbed [19]. Observations on primate taste fibres of the marmoset, Callithrix jacchus (Fig. $2 \mathrm{~A})$, showing that a group responding to citric is not clearly separated from the set responding to tannin/alkaloids, is part of the evidence. However, this type of correlation is poor or absent in the rhesus monkey, Macaca mulatta (Fig. 2B) and in the chimpanzee, Pan troglodytes (Fig. 2C).

Another issue is raised by sodium chloride, which elicits a clear signal in some primate taste fibres though it is present at undetectable concentrations in the natural foods of most extant primate species [13]. Among the fibres responding to sodium chloride in the chimpanzee, some also respond to $\mathrm{KCl}$, others to monosodium glutamate (MSG), and some to $\mathrm{KCl}$ and MSG [4-5]. Their response, in the rhesus monkey, is restricted to salts, but excludes $\mathrm{KCl}$ [6]. Since it is so important to monitor and maintain adequate levels of $\mathrm{Na}$, we may wonder why there is no evidence of selective pressure for an improved sensitivity and preference for sodium chloride in non-human primates. The answer probably lies in the complementary mechanisms that are involved in feeding behaviour [20], allowing adaptive responses to nutrients at undetectable concentration levels such as mineral micro-elements and vitamins. For such compounds, the response to beneficent effect triggers a positive conditioning to other sensory cues (tastes/odors) of the foodstuffs containing adequate proportions of micro-elements. 


\subsection{Taste as a target of evolutionary pressure}

Our data show that the target of evolutionary pressure is a set of chemical receptors that was probably not initially tuned for sweet, bitter, sour, or salty tastes, thus allowing a large flexibility in the long-term evolutionary response to variation in plant composition. The set of receptors best responding to soluble sugars of the fruits of the angiosperms have been retained mostly in the front part of the primate tongue, with the corresponding nerve fibres connected to primary taste areas of the brain stem eliciting a positive gusto-facial reflex [12]. The set of receptors best responding to alkaloids and tannins, or strong acids (eventually also to other secondary compounds not yet studied for taste, such as saponins and terpenes) have been selectively retained on the rear part of the tongue, and connected to the part of the brain stem eliciting a negative gusto-facial reflex. Taste receptors diversity still allows responses to substances that are uncommon or present at low concentration in the natural habitat of the primates. If such compounds are present at detectable concentration, the taste signal can elicit a conditioned (positive or negative) response. This obviously occurred with the hominids, when they started to cook foods and to add salt to improve the resulting taste [21], even though salty taste was not initially positively or negatively selected in wild primate taste responses.

Since our data from marmosets, rhesus monkeys, and chimpanzees reflect adaptations to discriminate, among a wide array of tasting compounds, what is beneficial from what is to be avoided, the additive tree concerning human taste thresholds, by virtue of its similarity with that of non-human primates, also reflects the evolutionary history of our tasting system.

\section{Version abrégée}

Nous avons utilisé une même méthode d'analyse des corrélations, afin de comparer les co-variations des réponses gustatives obtenues avec des primates non humains (fréquence des impulsions sur les fibres isolées du nerf de la gustation) et avec des échantillons de populations humaines (seuils de reconnaissance gustative en simple aveugle sur 412 sujets adultes). Les résultats obtenus avec des produits solubles analogues (fructose, saccharose, acide citrique, chlorure de sodium, quinine, tannin de chêne, acide tannique) montrent que les corrélations entre les réponses pour ces différents produits sont très comparables d'une espèce à l'autre, en dépit de la spécificité des méthodes utilisées dans chacune des deux approches. Chez l'homme, la corrélation entre la perception des deux sucres (fructose et saccharose) indique que les signaux perçus diffèrent sensiblement et n'impliquent donc pas un unique récepteur du goût sucré. En 
revanche, les corrélations significatives entre les perceptions du goût amer de la quinine et du goût des tannins (un goût astringent qui est plus qu'un simple phénomène tactile) mettent en évidence que plusieurs récepteurs périphériques sont communs à chacune de ces perceptions. L'absence de co-variation entre l'ensemble des tannins+quinine et celui des sucres montre que, parmi les transducteurs gustatifs mis en jeu pour chacun de ces groupes de substances, il n'y a pas de récepteur commun. Les corrélations entre les signaux enregistrés sur les fibres du nerf de la gustation des primates non humains ont également montré une dichotomie entre les perceptions: d'une part les fibres du nerf gustatif qui réagissent aux sucres présentent des différences entre fructose et saccharose (plus nettes chez le macaque); d'autre part, les réactions aux tannins et aux alcaloïdes co-varient chez toutes les espèces testées (ouistiti, macaque et chimpanzé). Dans tous les cas, la corrélation négative entre de ces deux ensembles de signaux correspondant respectivement à des substances bénéfiques (les sucres, source d'énergie) et à des produits que les primates doivent éviter (à effet toxique, comme beaucoup d'alcaloïdes, ou anti-nutriment, comme les tannins) montre qu'il n'y a pas de récepteurs périphériques communs à ces deux ensembles de réponses gustatives. Cette dichotomie apparaît comme le résultat de la co-évolution des primates et des angiospermes dont les fruits sucrés permettent la dissémination des graines, mais dont les teneurs en produits secondaires (alcaloïdes, tannins, terpènes, etc.) nécessitent une détection rapide et leur évitement grâce au réflexe gusto-facial. L'appareil gustatif des primates permet de détecter de nombreuses autres substances, en particulier le chlorure de sodium. Cependant il n'apparaît pas que le goût salé, tel qu'il est perçu et décrit par l'homme, résulte de la co-évolution avec des aliments potentiels des milieux naturels. L'absence de co-variation des signaux déclenchés par le sel avec les deux grands ensembles de perceptions (sucres et tannins+alcaloïdes), ainsi que les teneurs en chlorure de sodium des aliments naturels inférieures aux seuils de gustation des primates, remettent en cause la notion de "goûts de base". Comme dans les cas des produits de type PTC ou PROP (perçus comme amers par certains "goûteurs"), la détection des solutions concentrées de chlorure de sodium (le goût salé) ne serait que le résultat fortuit de la co-évolution d'un ensemble de gènes permettant aux primates une réaction rapide aux produits toxiques et aux substances énergétiques. L'importance du sel dans les civilisations montre que son intégration dans une alimentation élaborée est une adaptation culturelle qui aurait pu se manifester dès l'émergence des premiers hominidés.

Acknowledgements: Most research on human taste thresholds was supported by the European Union Program CEE DG V-SOC 97200420 05F02. Researches on isolated taste nerve fibres of non-human primates were carried out at Madison University (Department of Animal Health and Biomedical Sciences). Confrontation of results, and further discussion on their respective significance, have been carried out at the Muséum National d'Histoire Naturelle (Paris and Brunoy, France), where G. Hellekant was a visiting professor. 


\section{References}

[1] Janzen D.H., Complications in interpreting the chemical defenses of trees against tropical arboreal plant-eating vertebrates, in : G. G. Montgomery (éd.) The Ecology of Arboreal Folivores, Smithsonian Institution Press, Washington, DC, 1978, pp. 73-84.

[2] Hladik C.M., Robbe B., Pagezy H., Sensibilité différentielle des populations Pygmées et non Pygmées de forêt dense, de Soudaniens et d'Eskimos, en rapport avec l'environnement biochimique, C. R. Acad. Sci. Paris, 303 (1986) 453-458.

[3] Hladik C.M., Pasquet P. Simmen B., New perspective on taste and primate evolution: the dichotomy in gustatory coding for perception of beneficent vs. noxious substances as supported by correlations among human thresholds, Am. J. Phys. Anthropol. 117 (2002) 342-348.

[4] Hellekant G., Ninomiya Y., Bitter taste in single chorda tympani taste fibers on chimpanzee, Physiol. Behav. 56 (1994) 1185-1188.

[5] Hellekant G., Ninomiya Y., Danilova V., Taste in chimpanzees II: single chorda tympani fibers, Physiol. Behav. 61 (1997) 829-841.

[6] Hellekant G., Danilova V., Ninomiya, Y., Primate sense of taste: behavioral and single chorda tympani and glossopharyngeal nerve fibers recordings in the rhesus monkey, Journal of Neurophysiology 77 (1997) 978-993.

[7] Hellekant G., Ninomiya Y., Danilova, V., Taste in chimpanzees. III: Labeled-line coding in sweet taste, Physiol. Behav. 65 (1998) 191-200.

[8] Danilova V., Hellekant G., Roberts T., Tinti J.-M., Nofre C., Behavioral and single chorda tympani taste fiber responses in the common marmoset, Callithrix jacchus jacchus, Annals N. Y. Acad. Sci. 855 (1998) 160-164.

[9] Sappath S., Tersky A., Additive similarity trees, Psychometrika, 42 (1977) 319-345.

[10] Simmen B., Hladik A., Ramasiarisoa P. L., laconelli S., Hladik C. M., Taste discrimination in lemurs and other primates, and the relationships to distribution of plant allelochemicals in different habitats of Madagascar, in : Rakotosamimanana B., Rasamimanana H., Ganzhorn J.U., Goodman S.M. (éd.), New directions in lemur studies, Kluwer Academic/Plenum Publishers, New York, 1999, pp. 201-219.

[11] Delwiche J.F., Buletic Z., Breslin P.A.S., Covariation in individuals' sensitivities to bitter compounds: evidence supporting multiple receptors/transduction mechanisms, Perception and Psychophysics, 63 (2001) 761-776.

[12] Steiner J.E., Glaser D., Hawilo M.E., Berridge K.C., Comparative expression of hedonic impact; affective reactions to taste by human infants and other primates, Neuroscience and Behavioral Reviews 25 (2001) 53-74.

[13] Hladik C.M., Simmen B., Taste perception and feeding behavior in nonhuman primates and human populations, Evolutionary Anthropology 5 (1996) 58-71.

[14] Simmen B., Hladik C. M., Sweet and bitter taste discrimination in Primates: Scaling effects across species, Folia Primatol. 69 (1998) 129-138.

[15] Matsunami H., Montmayeur J.-P., Buck L., A family of candidate taste receptors in human and mouse, Nature 404 (2000) 601-603.

[16] Blakesly, A. F., Genetics of sensory thresholds: test for phenylthiocarbamide, Proceedings of the National Academy of Sciences, USA, 18 (1932) 120-130.

[17] Bartoshuk L. M., Bitter taste of saccharin related to the genetic ability to taste the bitter substance 6-n-propylthiouracyl, Science 206 (1979) 934-935.

[18] Olson J.M., Boehnke M., Neiswanger K., Roche A.F., Siervogel R.M., Alternative genetic models for the inheritance of the phenylthiocarbamide taste deficiency, Genetic Epidemiology 6 (1989) 423-434. 
[19] Ungar P.S., Fruit preferences of four sympatric primate species at Ketambe, Northern Sumatra, Indonesia, Int. J. Primatol. 16 (1995) 221-245.

[20] Toates F., Motivational Systems, Cambridge University Press, Cambridge, 1986.

[21] Hladik C.M., Pasquet P., The human adaptations to meat eating: a reappraisal, Human Evolution (in press)

\section{Homo sapiens$$
(\mathrm{N}=412)
$$

Taste recognition thesholds

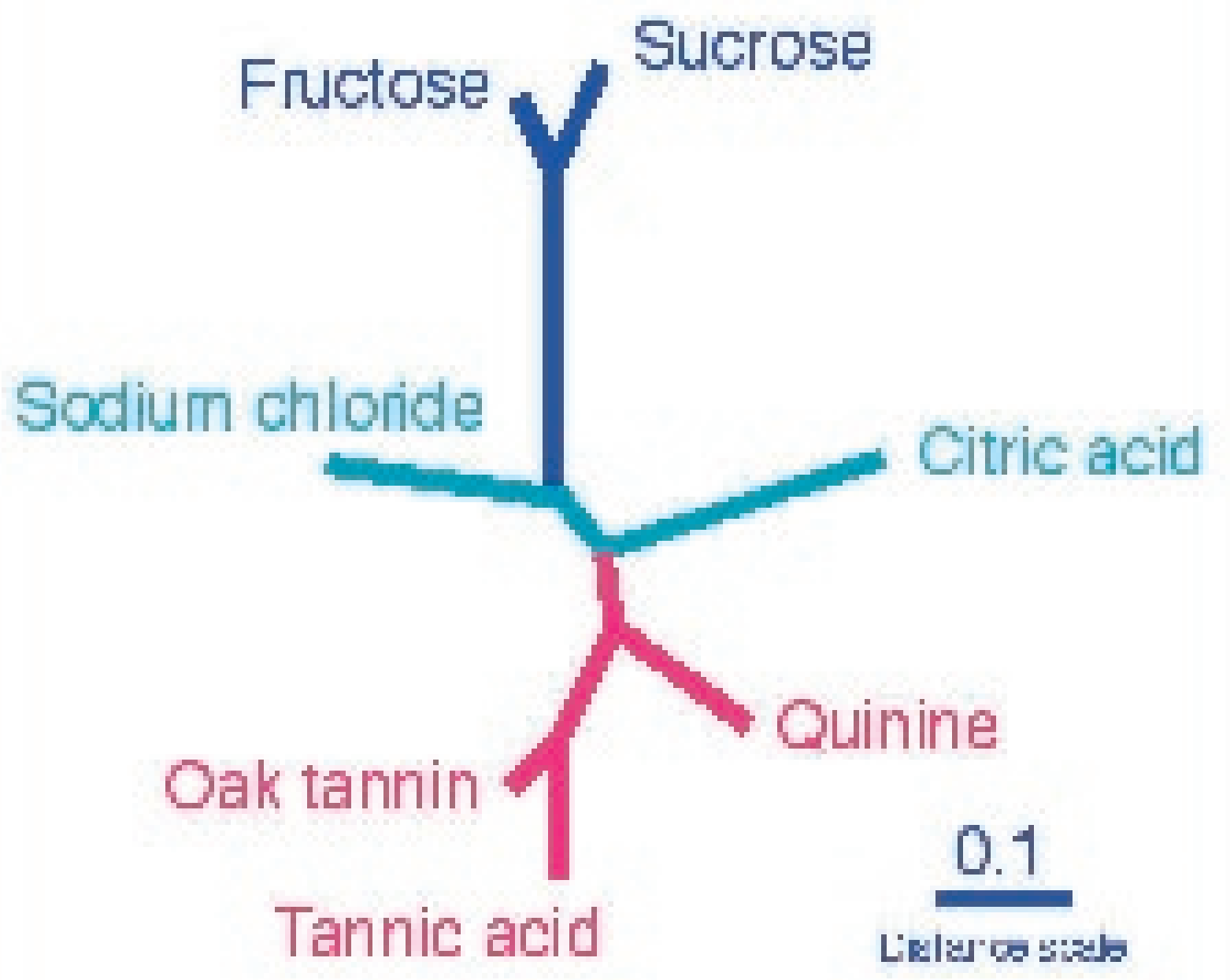

Figure 1. Additive tree (stress $=2.5 \%$ ) showing relationships between taste recognition thresholds for 412 human subjects (log concentrations of the solutions). 


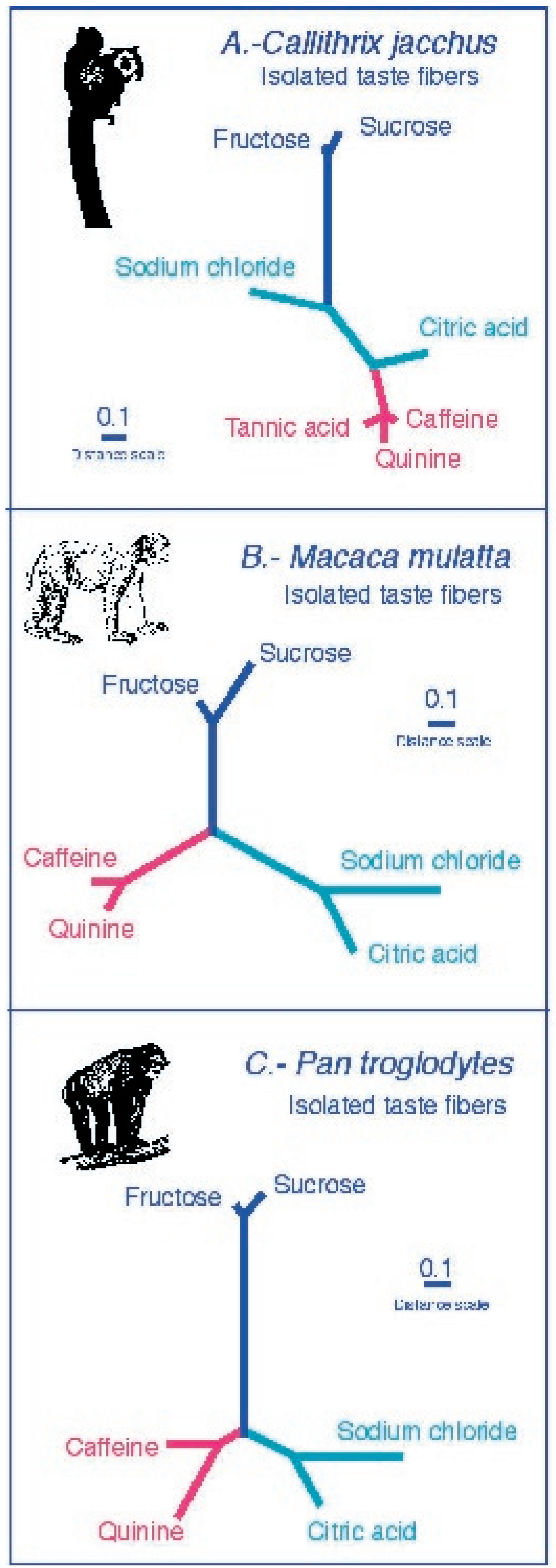

Figure 2. Additive trees showing relationships between taste signals recorded on isolated taste fibres in three non-human primate species, respectively for the marmoset, Callithrix jacchus (A; stress $=1.5 \%$ ), the rhesus monkey, Macaca mulatta (B; stress $=5.0 \%)$, and the chimpanzee, Pan troglodytes $(\mathrm{C}$; stress $=3.5 \%)$. 